\title{
An Efficient Protocol for Facile Synthesis of New 5-Substituted-1H-Tetrazole Derivatives Using Copper-Doped Silica Cuprous Sulfate (CDSCS) as Heterogeneous Nano-Catalyst
}

\author{
Mohammad Navid Soltani Rad* \\ Medicinal Chemistry Research Laboratory, Department of Chemistry, Shiraz University of \\ Technology, 71555-313 Shiraz, Iran
}

\begin{abstract}
A facile and highly efficient protocol for synthesis of new 5-substituted- $1 H$-tetrazoles derivatives using copper-doped silica cuprous sulfate (CDSCS) is described. In this method, the cycloaddition reaction of sodium azide with structurally diverse nitriles involving bioactive $N$-heterocyclic cores exploiting CDSCS in refluxing $\mathrm{H}_{2} \mathrm{O} / i-\mathrm{PrOH}(1: 1, \mathrm{v} / \mathrm{v})$ furnishes the corresponding 5-substituted$1 H$-tetrazoles in good to excellent yields (up to 93\%). The influence of parameters effective in progress of reaction including solvent type, temperature and catalyst was studied and discussed. In this protocol, CDSCS was proved to be an efficient heterogeneous nano-catalyst to easily achieve the new tetrazole derivatives. The advantages of CDSCS in current protocol known are its cheapness, thermal and chemical stability, ease of recyclability and reusability for several consecutive runs without significant decline in its reactivity.
\end{abstract}

Keywords: azide, CDSCS, cycloaddition, nitrile, $1 H$-tetrazole

\section{Introduction}

Tetrazole and its derivatives are an important class of $N$-heterocyclic compounds exhibiting widespread applications. ${ }^{1,2}$ Tetrazoles are extensively applied in different industries as instance: stabilizers in photography and photo imaging, ${ }^{3,4}$ explosives in rocket propellants, ${ }^{5-7}$ chelating agents in coordination chemistry, ${ }^{8,9}$ plant growth regulators, herbicides, fungicides in agriculture, ${ }^{3,10}$ and anti-wears and frictions in lubricants. ${ }^{11}$ Additionally, tetrazoles can be served as bioisosteres for the carboxylic acids. ${ }^{12-14}$ Replacing a carboxyl group with tetrazolyl moiety extensively improves the metabolic stability, bioavailability and cell permeability of a drug molecule. ${ }^{15,16}$ When increase in the lipophilicity factor $(\log \mathrm{P})$ for a drug molecule involving carboxylic moiety is desired, one can replace the carboxylic moiety with tetrazole as a more lipophilic bioisostere. Consequently, tetrazoles are widely applied in synthesis of many well-known drugs like losartan, ${ }^{17-19}$ candesartan, ${ }^{18,19}$ zolarsartan ${ }^{18,19}$ and valsartan. ${ }^{17}$ In addition, tetrazoles exhibit varied biological activities such as antihypertensive, ${ }^{17-21}$ antibacterial, ${ }^{22,23}$ antifungal, ${ }^{24,25}$ anticonvulsant, ${ }^{26}$ anti-inflammatory, ${ }^{27,28}$ antitubercular, ${ }^{29}$

*e-mail: soltani@sutech.ac.ir anticancer, ${ }^{30}$ antineoplastic, ${ }^{31}$ antiallergic, ${ }^{32-34}$ and antiviral ${ }^{35}$ especially anti-HIV ${ }^{36}$ activities.

The synthesis of tetrazole and its derivatives has attracted considerable attention since the broad utilities found for tetrazoles. In this context, the different preparative methods have been emerged so far..$^{37,38}$ Among them, the $[3+2]$-cycloaddition reaction of nitriles with azides is a well-known and most extensively studied and used procedure for synthesis of diverse 5-substituted$1 H$-tetrazoles. ${ }^{39,40}$ In this regard, several homogeneous reagents or catalysts have been developed to synthesize 5 -substituted- $1 H$-tetrazoles. ${ }^{41,42}$ Although these methods exhibit some advantages to access $1 H$-tetrazoles, their scale up synthesis are restricted by one or more disadvantages such as harsh reaction conditions, low yields, long reaction times, the use of strong Lewis acids, the in situ generation of $\mathrm{HN}_{3}$ as a highly dangerous volatile material with a great risk of eruption and toxicity, production of the stable metal-tetrazole complexes, the use of expensive and toxic metals or solvents, tedious work-up procedure and failure to undertake the recovery or reusability of the catalyst.

Nowadays, heterogeneous catalysts have gained considerable attention due to both economic and environmental standpoints. The successful applications of heterogeneous systems in various organic transformations 
are well documented. Employing the heterogeneous catalysts often leads to the simple experimental procedures, mild reaction conditions, recovery and reusability of the catalyst, the minimization of undesirable chemical wastes, and the production of large quantities of products by using a small amount of catalyst. Thus, the exploit of heterogeneous catalysis has an exact superiority over homogeneous catalyst. In recent decade, some heterogeneous catalytic systems were developed to promote the synthesis of 5-substituted-1H-tetrazoles; ${ }^{43-55}$ nevertheless, drawbacks are usually accompanied with these heterogeneous catalysts comprising: $(i)$ the strong acidic nature of some catalysts that largely aggravates the release of dangerous $\mathrm{HN}_{3}$; (ii) the use of weakly bonded or none-bonded metal salts supported on mineral supports which normally lead to desorption of active metal species during the reaction progress or work-up procedure; (iii) the formation of stable metal-tetrazole complexes that makes the tedious work-up procedure and $(i v)$ the thermal or chemical instability. Thus, the employment of a heterogeneous catalyst that obviates the above drawbacks is of particular interest.

Silica-based catalysts offer several advantages like cheapness, mild reaction conditions, high yields and selectivity, non-corrosive properties, ease of handling and preparation. In addition, they could be easily removed from the reaction mixture, recovered, and reused by a simple flash filtration. Recently, we have reported the synthesis, characterization, and application of copper-doped silica cuprous sulfate (CDSCS) as a novel and efficient heterogeneous nano-catalyst for the $\mathrm{Cu}^{\mathrm{I}}$-catalyzed 'Click' synthesis of 1,4-disubstituted 1,2,3-triazoles ${ }^{56}$ and also 3,5-disubstituted isoxazoles. ${ }^{57}$ In light of the unique biological activities of tetrazoles and also in continuation of our ongoing research in utilizing CDSCS in organic synthesis, ${ }^{56-58}$ we herein report a practical and environmentally benign catalytic protocol for efficient synthesis of 5-substituted$1 H$-tetrazole derivatives using CDSCS (Scheme 1). In this synthesis, the desired nitriles 1 were primarily achieved by the reaction of diverse nucleophiles with 2-chloroacetonitrile

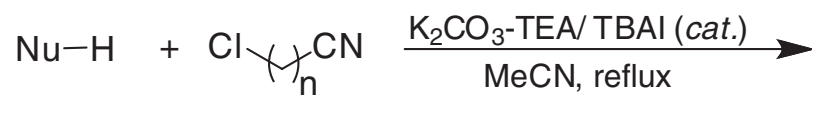

$\mathrm{n}=1,2$
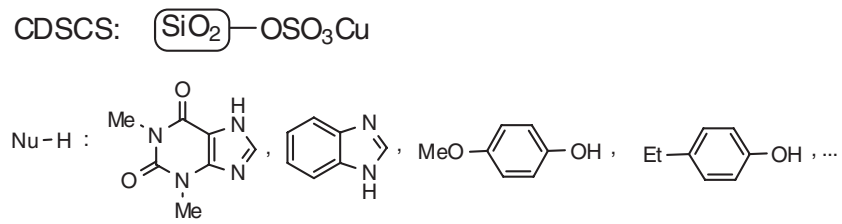

Scheme 1. CDSCS catalyzed synthesis of 5-substituted $1 H$-tetrazoles. or 3-chloropropanenitrile in the presence of an equimolar mixture of triethylamine (TEA)- $\mathrm{K}_{2} \mathrm{CO}_{3}$ and catalytic amount of tetrabutylammonium iodide (TBAI) in $\mathrm{MeCN}$ at reflux condition. Then, to access tetrazoles $\mathbf{2}$, the cycloaddition reaction of nitriles $\mathbf{1}$ with sodium azide was carried out utilizing CDSCS in $\mathrm{H}_{2} \mathrm{O} / i$-PrOH at reflux condition.

\section{Results and Discussion}

The first step of this synthetic approach was initiated by the preparation of the essential nitriles 1 . In this context, various nucleophiles comprising azole derivatives, purine and pyrimidine nucleobases and phenols underwent the $\mathrm{N}$ - or $\mathrm{O}$-alkylation reaction with 2-chloroacetonitrile or 3 -chloropropanenitrile through the $\mathrm{S}_{\mathrm{N}} 2$-type reaction. The reaction of the selected nucleophiles with above chloronitriles was carried out using TEA-K $\mathrm{CO}_{3}(1: 1)$ in the presence of TBAI (cat.) in refluxing $\mathrm{MeCN}$ (anhyd.) to gain 1. Afterward, to assess the optimized reaction condition for [3+2]-cycloaddition of $\mathbf{1}$ with $\mathrm{NaN}_{3}$, the influence of various parameters including temperature, solvent, and catalyst was studied. In this regard, the cycloaddition reaction of 2-(1H-benzo[ $d]$ imidazol-1-yl)acetonitrile (1a) with $\mathrm{NaN}_{3}$ was selected as a sample reaction.

To progress the reaction efficiently, the choice of an appropriate solvent is crucial. Among tested solvents, the use of water has attracted enormous interest in organic transformations, since water is a cheap, clean, and universal solvent exhibiting extraordinary physical properties and enviro-economic benefits. ${ }^{59}$ In this regard, the model reaction was carried out in an aquatic media at room temperature. However, the corresponding tetrazole 2a was obtained only in $19 \%$ yield (Table 1 , entry 1 ). To increase the reaction yield, the model reaction was investigated at varied temperatures (Table 1). As indicated in Table 1, the use of pure water at different temperatures failed to afford the satisfactory results even at reflux condition. This can be attributed to the lack of solubility of nitrile 1a in pure water. Consequently, the influence of several 1:1 (v/v) solutions

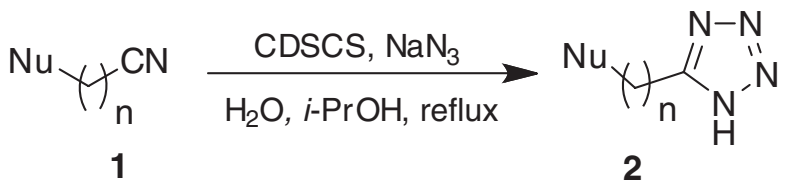


Table 1. Effect of solvent and temperature on the model reaction ${ }^{\mathrm{a}}$<smiles>N#CCn1cnc2ccccc21</smiles>

$1 a$

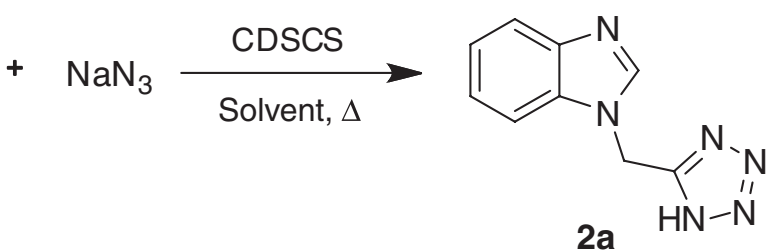

$2 a$

\begin{tabular}{|c|c|c|c|c|}
\hline entry & Solvent & $\mathrm{T} /{ }^{\circ} \mathrm{C}$ & time $/ \mathrm{h}$ & Yield $^{\mathrm{b}} / \%$ \\
\hline 1 & $\mathrm{H}_{2} \mathrm{O}$ & r.t. & 24 & 19 \\
\hline 2 & $\mathrm{H}_{2} \mathrm{O}$ & 50 & 10 & 28 \\
\hline 3 & $\mathrm{H}_{2} \mathrm{O}$ & 60 & 7 & 39 \\
\hline 4 & $\mathrm{H}_{2} \mathrm{O}$ & 70 & 7 & 42 \\
\hline 5 & $\mathrm{H}_{2} \mathrm{O}$ & 80 & 5 & 50 \\
\hline 6 & $\mathrm{H}_{2} \mathrm{O}$ & reflux & 4 & 58 \\
\hline 7 & $\mathrm{H}_{2} \mathrm{O} / i-\mathrm{PrOH}^{\mathrm{c}}$ & r.t. & 18 & 62 \\
\hline 8 & $\mathrm{H}_{2} \mathrm{O} / i-\mathrm{PrOH}^{\mathrm{c}}$ & reflux & 4 & 93 \\
\hline 9 & $\mathrm{H}_{2} \mathrm{O} / \mathrm{Me}_{2} \mathrm{CO}^{\mathrm{c}}$ & reflux & 6 & 40 \\
\hline 10 & $\mathrm{H}_{2} \mathrm{O} / \mathrm{DMF}^{\mathrm{c}}$ & reflux & 7 & 46 \\
\hline 11 & $\mathrm{H}_{2} \mathrm{O} / \mathrm{DMSO}^{\mathrm{c}}$ & reflux & 7 & 49 \\
\hline 12 & $\mathrm{H}_{2} \mathrm{O} / \mathrm{NMP}^{\mathrm{c}}$ & reflux & 6 & 53 \\
\hline 13 & $\mathrm{H}_{2} \mathrm{O} / \mathrm{HMPA}^{\mathrm{c}}$ & reflux & 7 & 50 \\
\hline 14 & $\mathrm{H}_{2} \mathrm{O} / \mathrm{THF}^{\mathrm{c}}$ & reflux & 8 & 81 \\
\hline 15 & THF & reflux & 12 & 46 \\
\hline 16 & $i-\mathrm{PrOH}$ & reflux & 5 & 60 \\
\hline
\end{tabular}

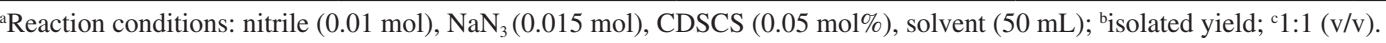

of $\mathrm{H}_{2} \mathrm{O}$ with some water miscible organic solvents were examined (Table 1).

As indicated in Table 1 , a solution of $\mathrm{H}_{2} \mathrm{O} / i-\mathrm{PrOH}$ $(1: 1, \mathrm{v} / \mathrm{v})$ was found to be the most appropriate solvent for synthesis of tetrazole derivatives in the presence of CDSCS (Table 1, entry 8). Therefore, this solvent was used for all subsequent reactions. Employing $\mathrm{H}_{2} \mathrm{O} /$ tetrahydrofuran (THF) $(1: 1, v / v)$ solution afforded the corresponding tetrazole in $81 \%$ yield after $8 \mathrm{~h}$ (Table 1, entry 14). Moreover, the combination of water with other miscible solvents like acetone, dimethylformamide (DMF), dimethyl sulfoxide (DMSO), $N$-methylpyrrolidone (NMP), and hexamethylphosphoramide (HMPA) yielded the moderate amount of product (Table 1, entries 9-13). In addition, when THF and/or $i$-PrOH were used separately as a solvent, 2a was obtained in 46 and $60 \%$ yields, respectively (Table 1, entries 15,16$)$. Also, in an attempt to carry out the reaction in $\mathrm{H}_{2} \mathrm{O} / i-\mathrm{PrOH}(1: 1, \mathrm{v} / \mathrm{v})$ solution at r.t. 2a was produced in $62 \%$ yield after $18 \mathrm{~h}$ (Table 1, entry 7 ).

It is well understood that cycloaddition reaction between nitrile and azide is very slowly achieved in the absence of a suitable catalyst and thus it is unsuitable for large scale synthesis. In this connection, the choice of an efficient catalyst is critically essential for progress of the reaction. To investigate the catalytic potency of CDSCS, the effect of different catalysts was studied and compared with
CDSCS (Table 2). To this end, we examined the potency of several heterogeneous or homogeneous catalysts including Lewis and proton acids, solid supports, and ammonium salts which are often applied in synthesis of tetrazole derivatives. As the results in Table 2 indicate, higher yield of $\mathbf{2 a}$ in shorter reaction time were observed utilizing CDSCS in comparison with other tested catalysts. The use of other catalysts yielded 2a in moderate to reasonable amounts in variable times.

The optimized stoichiometric ratio of nitrile/sodium azide to access 2a using CDSCS (0.05 mol\%) was determined to be $1: 1.5$.

The generality and versatility of current protocol was screened by applying the optimized condition to various structurally diverse nitriles 1a-1o (Table 3). Due to Table 3, CDSCS proved to be a convenient and efficient heterogeneous nano-catalyst for cycloaddition reaction of sodium azide with different nitriles tethered to bioactive cores. As shown in Table 3, nitriles bearing azole derivatives (Table 3, entries 1-4, 10, 11), xanthine (Table 3, entry 9), purine and pyrimidine nucleobases (Table 3, entries 5 and 6) were employed to produce their corresponding 5 -substituted- $1 \mathrm{H}$-tetrazole derivatives in good to excellent yields. Moreover, nitriles involving amine (Table 3, entry 12), cyclic amides (Table 3, entries 7 and 8), and phenols (Table 3, entries 13-15) underwent 
Table 2. Comparing the influence of different catalysts with CDSCS in synthesis of $\mathbf{2 a}^{\mathrm{a}}$<smiles>N#CCn1cnc2ccccc21</smiles>

$1 a$<smiles>O=[N+]([O-])[O-]</smiles>
$2 a$

\begin{tabular}{|c|c|c|c|}
\hline entry & Catalyst & time / h & Yield $\mathrm{b} / \%$ \\
\hline 1 & $\mathrm{TBAF}^{\mathrm{c}}$ & 24 & 40 \\
\hline 2 & $\mathrm{NH}_{4} \mathrm{Cl}^{\mathrm{c}}$ & 24 & 59 \\
\hline 3 & $\mathrm{Et}_{3} \mathrm{~N} \cdot \mathrm{HCl}^{\mathrm{c}}$ & 12 & 75 \\
\hline 4 & $\mathrm{FeCl}_{3}-\mathrm{SiO}_{2}^{\mathrm{c}}$ & 24 & 54 \\
\hline 5 & $\operatorname{CDSCS}^{\mathrm{d}}$ & 4 & 93 \\
\hline 6 & amberlyst- $15^{\mathrm{c}}$ & 24 & 30 \\
\hline 7 & $\mathrm{HCl}^{\mathrm{c}}$ & 24 & 48 \\
\hline 8 & silica sulfuric acid & 12 & 79 \\
\hline 9 & $\mathrm{Cu}_{2} \mathrm{O}^{\mathrm{c}}$ & 10 & 67 \\
\hline 10 & $\mathrm{CuFe}_{2} \mathrm{O}_{4}{ }^{\mathrm{c}}$ & 12 & 70 \\
\hline 11 & Zeolite $^{\mathrm{d}}$ & 24 & 52 \\
\hline 12 & $\mathrm{ZnBr}_{2}^{\mathrm{c}}$ & 5 & 67 \\
\hline 13 & $\mathrm{ZnO}^{\mathrm{c}}$ & 15 & 53 \\
\hline 14 & $\mathrm{AlCl}_{3}{ }^{\mathrm{c}}$ & 10 & 72 \\
\hline 15 & $\mathrm{TMSCl}^{\mathrm{c}}$ & 12 & 41 \\
\hline 16 & $\mathrm{H}_{3} \mathrm{PW}_{12} \mathrm{O}_{40}{ }^{\mathrm{e}}$ & 8 & 50 \\
\hline
\end{tabular}

${ }^{a}$ Reaction conditions: nitrile $(0.01 \mathrm{~mol}), \mathrm{NaN}_{3}(0.015 \mathrm{~mol})$, catalyst, $\mathrm{H}_{2} \mathrm{O} / i-\mathrm{PrOH}(50 \mathrm{~mL})$; bisolated yield; ' $a$ an equimolar amount was used; ${ }^{\mathrm{d}} 0.05 \mathrm{~mol} \%$; ${ }^{\mathrm{e}} 1 \mathrm{~mol} \%$.

cycloaddition reaction with azide to obtain the desired tetrazole derivatives. The structures of all synthesized compounds were confirmed by ${ }^{1} \mathrm{H}$ and ${ }^{13} \mathrm{C}$ NMR, elemental analysis, mass and infrared (IR) spectroscopy techniques.

The applicability of the present protocol in preparative scale was also examined. In this context, the cycloaddition reaction of nitrile 1a with $\mathrm{NaN}_{3}$ was performed on a 100-mmol scale. Interestingly, 2a was obtained in an excellent yield (89\%) after $4 \mathrm{~h}$ which is comparable to smaller scale synthesis (Table 3, entry 1).

The recoverability and reusability of the catalyst is an important issue from different aspects like commercial applications and environmental concerns. In this connection, the reusability of CDSCS was investigated for sample reaction (Table 4).

The separation of the catalyst from the reaction media was conducted using a sintered glass funnel. The catalyst was then washed with ethyl acetate $(2 \times 15 \mathrm{~mL})$ and dried in a vacuum oven at $90{ }^{\circ} \mathrm{C}$ for $20 \mathrm{~min}$. The catalyst was sequentially applied for 5 runs without the addition of the fresh catalyst to the reaction media. As shown in Table 4, the catalyst can be reused for many consecutive times without considerable decline in its catalytic activity. To determine the amount of leached $\mathrm{Cu}$ from CDSCS, the copper content of catalyst was determined using inductively coupled plasma (ICP) analysis for both fresh and reused catalyst (after 5 runs). Based on the ICP results, the leached $\mathrm{Cu}$ was found to be $0.014 \%$, which is negligible.

\section{Conclusions}

In conclusion, we have described a convenient protocol for facile and high yield synthesis of the new structurally diverse 5-substituted- $1 H$-tetrazoles utilizing CDSCS as a highly efficient heterogeneous nano-catalyst. CDSCS was proved to be a useful catalyst for cycloaddition reaction of sodium azide with different nitriles involving bioactive cores in $\mathrm{H}_{2} \mathrm{O} / i-\mathrm{PrOH}(1: 1, \mathrm{v} / \mathrm{v})$ at reflux condition, which affords the corresponding tetrazole derivatives in good to excellent yields. The use of ecofriendly solvent, the reusability of the catalyst, the simplicity of the process, cheapness, and applicability in preparative scale are benefits that can be mentioned for current synthetic protocol.

\section{Experimental}

\section{General}

All chemicals were purchased from either Fluka or Merck. Reactions were followed by TLC using 
Table 3. Synthesis of 5-substituted-1H-tetrazole derivatives using CDSCS ${ }^{\text {a }}$

\begin{tabular}{|c|c|c|c|c|}
\hline entry & Nitrile & Product $^{\mathrm{b}}$ & time $/ \mathrm{h}$ & Yield" $/ \%$ \\
\hline 1 & & & 4 & 93 \\
\hline 2 & & $2 b$ & 4 & 89 \\
\hline 3 & $1 c$ & $\begin{array}{l}\mathrm{CH}_{3} \\
2 \mathrm{c}\end{array}$ & 5 & 85 \\
\hline 4 & & $\mathrm{Ph} 2 \mathrm{~d}$ & 6 & 87 \\
\hline 5 & & & 3.5 & 83 \\
\hline 6 & & $2 f$ & 5.5 & 82 \\
\hline 7 & & $2 g$ & 3 & 87 \\
\hline 8 & 11 & & 3.5 & 91 \\
\hline
\end{tabular}


Table 3. Synthesis of 5-substituted- $1 H$-tetrazole derivatives using $\operatorname{CDSCS}^{\text {a }}$ (cont.)

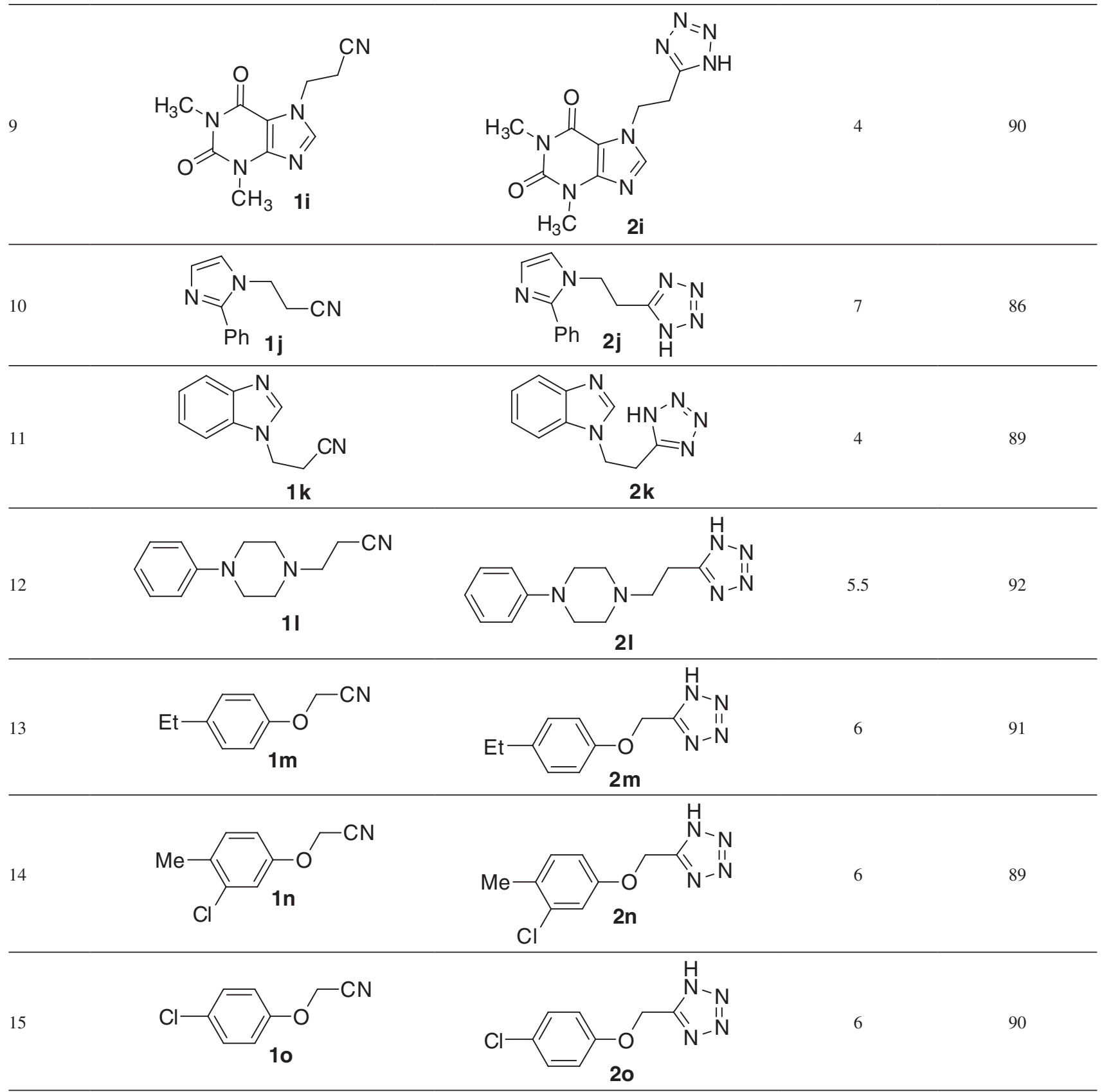

Reaction conditions: nitrile $(0.01 \mathrm{~mol}), \mathrm{NaN}_{3}(0.015 \mathrm{~mol}), \mathrm{CDSCS}(0.05 \mathrm{~mol} \%), \mathrm{H}_{2} \mathrm{O} / \mathrm{i}$ - $\mathrm{PrOH}(50 \mathrm{~mL}) ;$ ball products were characterized by ${ }^{1} \mathrm{H}$ and ${ }^{13} \mathrm{C} \mathrm{NMR}$, IR, CHN, and MS analysis; cisolated yield.

SILG/UV 254 silica-gel plates. The fresh CDSCS was prepared according to our previous reported procedure. ${ }^{56,58}$ Column chromatography was performed on silica gel 60 (0.063-0.200 mm, 70-230 mesh; ASTM). Melting points were measured using Electrothermal IA 9000 melting point apparatus in open capillary tubes and are uncorrected. IR spectra were obtained using a Shimadzu FTIR-8300 spectrophotometer. ${ }^{1} \mathrm{H}$ and ${ }^{13} \mathrm{C}$ NMR spectrum was recorded on Brüker Avance-DPX-250/400 spectrometer operating at 250/62.5 and/or 400/100 MHz, respectively. Chemical shifts are given in $\delta$ relative to tetramethylsilane (TMS) as an internal standard, coupling constants $J$ are given in $\mathrm{Hz}$. Abbreviations used for ${ }^{1} \mathrm{H}$ NMR signals are: $\mathrm{s}=$ singlet, $\mathrm{d}=$ doublet, $\mathrm{t}=$ triplet, $\mathrm{q}=$ quartet, $\mathrm{m}=$ multiplet, $\mathrm{br}=$ broad and etc. GC-MS was performed on a Shimadzu GCMS-QP1000-EX apparatus $(\mathrm{m} / \mathrm{z}$; rel. \%). Elemental analyses were performed on a PerkinElmer 240-B microanalyzer. 
Table 4. The reusability of CDSCS in successive trails for synthesis of $\mathbf{2} \mathbf{a}^{\mathrm{a}}$

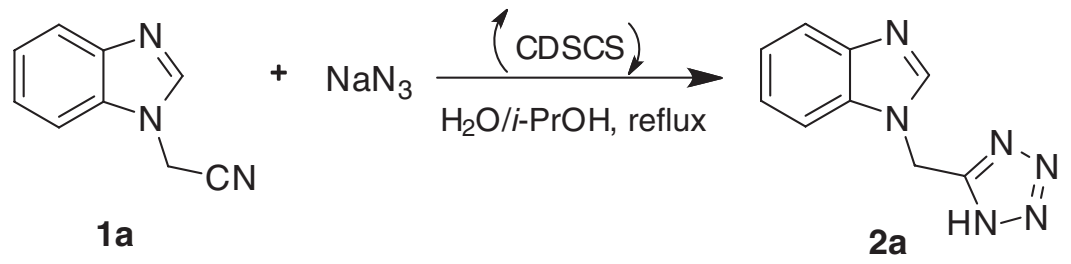

\begin{tabular}{|c|c|c|}
\hline entry $^{\mathrm{b}}$ & time / h & Yield $^{\mathrm{c}} / \%$ \\
\hline 1 & 4 & 93 \\
\hline 2 & 4 & 93 \\
\hline 3 & 4.5 & 91 \\
\hline 4 & 4.5 & 90 \\
\hline 5 & 5 & 87 \\
\hline
\end{tabular}

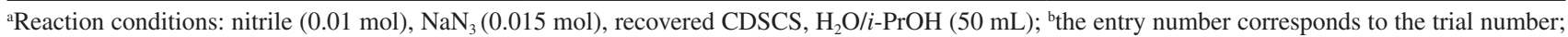
cisolated yield.

\section{General procedure for synthesis of alkyl nitriles 1a-10}

In a double-necked round bottom flask $(100 \mathrm{~mL})$ equipped with a condenser, it was added a mixture, consisting of nucleophile (including: $N$-heterocyclic compounds or phenolic derivatives) (0.01 mol), 2-chloroacetonitrile or 3-chloropropanenitrile (0.013 mol), $\mathrm{Et}_{3} \mathrm{~N}(0.01 \mathrm{~mol}), \mathrm{K}_{2} \mathrm{CO}_{3}(0.01 \mathrm{~mol})$, and a catalytic amount of TBAI $(0.1 \mathrm{~g})$ in anhydrous $\mathrm{MeCN}(40 \mathrm{~mL})$. The mixture was refluxed until TLC monitoring indicates no further improvement in the reaction. The solvent was evaporated in vacuo and the remaining foam was dissolved in $\mathrm{CHCl}_{3}(100 \mathrm{~mL})$ and subsequently washed with water $(2 \times 100 \mathrm{~mL})$. The organic layer was dried $\left(\mathrm{Na}_{2} \mathrm{SO}_{4}\right)$ and evaporated. The crude product was purified by column chromatography on silica gel.

General procedure for synthesis of 5 -substituted-1 $\mathrm{H}$ tetrazole 2a-2o

In a double-necked round bottom flask (100 mL) equipped with a condenser, it was added a mixture, consisting of alkyl nitrile $(0.01 \mathrm{~mol}), \mathrm{NaN}_{3}(0.015 \mathrm{~mol})$, and CDSCS $(0.3 \mathrm{~g}, 0.05 \mathrm{~mol} \%)$ in $\mathrm{H}_{2} \mathrm{O} / i-\mathrm{PrOH}(1: 1 \mathrm{v} / \mathrm{v}$, $50 \mathrm{~mL}$ ). The mixture was heated at reflux until TLC monitoring indicates no further improvement in the conversion (Table 3 ). The reaction mixture was then cooled to room temperature, vacuum-filtered using a sinteredglass funnel and the residue was washed with ethyl acetate $(2 \times 20 \mathrm{~mL})$. The filtrate was treated with $5 \mathrm{~N} \mathrm{HCl}$ to reach $\mathrm{pH}=3$ and it was allowed to stir for 30 minutes. Subsequently, the organic layer was separated, dried over anhydrous $\mathrm{Na}_{2} \mathrm{SO}_{4}$ and evaporated. The crude product was purified by recrystallization and/or column chromatography on silica gel eluted with proper solvents.

\section{1-((1H-Tetrazol-5-yl)methyl)-1H-benzo[d]imidazole (2a)}

Recrystallization (EtOAc) afforded a yellow solid; yield: $1.86 \mathrm{~g}(93 \%)$; mp 235-240 ${ }^{\circ} \mathrm{C}$ (dec.); IR (KBr) $\mathrm{v} / \mathrm{cm}^{-1}$ 3385, 3100, 2968, 2800, 1616, 1462, 1410; ${ }^{1} \mathrm{H}$ NMR $\left(250 \mathrm{MHz}, \mathrm{DMSO}-d_{6}\right) \delta 8.28(\mathrm{~s}, 1 \mathrm{H}, \mathrm{C}(2)-\mathrm{H}$, benzimidazole), 7.64-7.61 ( $\mathrm{m}, 2 \mathrm{H}$, aryl), 7.22-7.13 (m, $2 \mathrm{H}$, aryl), 5.55 (s, 2H, $\mathrm{NCH}_{2}$ ), 2.51 (s, 1H, exchangeable with $\mathrm{D}_{2} \mathrm{O}, \mathrm{NH}$, tetrazole); ${ }^{13} \mathrm{C}$ NMR $\left(250 \mathrm{MHz}\right.$, DMSO- $\left.d_{6}\right)$ $\delta$ 51.7, 116.6, 117.8, 122.2, 123.2, 133.6, 137.5, 145.6, 155.6; MS (EI): $m / z(\%)=200(14.5)\left[\mathrm{M}^{+}\right]$; anal. calcd. for $\mathrm{C}_{9} \mathrm{H}_{8} \mathrm{~N}_{6}$ : C, 53.99; H, 4.03; N, 41.98; found: C, 54.06; $\mathrm{H}, 4.15$; N, 41.92.

1-((1H-Tetrazol-5-yl)methyl)-2-methyl-1H-benzo[d]imidazole (2b)

Recrystallization (EtOAc) afforded a creamy solid; yield: $1.90 \mathrm{~g}(89 \%)$; $\mathrm{mp}>300{ }^{\circ} \mathrm{C}$ (dec.); IR (KBr) $v / \mathrm{cm}^{-1}$ 3384, 3100, 2982, 1619, 1580, 1480; ${ }^{1} \mathrm{H}$ NMR (250 MHz, DMSO- $\left.d_{6}\right) \delta$ 7.57-7.46 (m, 2H, aryl), 7.16-7.08 (m, 2H, aryl), $5.46\left(\mathrm{~s}, 2 \mathrm{H}, \mathrm{NCH}_{2}\right), 4.55(\mathrm{~s}, 1 \mathrm{H}$, exchangeable with $\mathrm{D}_{2} \mathrm{O}, \mathrm{NH}$, tetrazole), $2.67\left(\mathrm{~s}, 3 \mathrm{H}, \mathrm{CH}_{3}\right) ;{ }^{13} \mathrm{C} \mathrm{NMR}$ $\left(250 \mathrm{MHz}, \mathrm{DMSO}-d_{6}\right) \delta 17.9,49.1,115.5,116.6,121.5$, 123.0, 134.7, 140.3, 151.2, 158.4; MS (EI): $m / z(\%)=214$ (11.4) $\left[\mathrm{M}^{+}\right]$; anal. calcd. for $\mathrm{C}_{10} \mathrm{H}_{10} \mathrm{~N}_{6}$ : C, 56.07; H, 4.71; N, 39.23; found: C, 56.19; H, 4.62; N, 39.35.

5-((2-Methyl-4-nitro-1 $H$-imidazol-1-yl)methyl)-1 $H$-tetrazole (2c)

Column chromatography (silica gel, EtOAc-MeOH, 1:1) afforded a brown solid; yield: $1.77 \mathrm{~g}(85 \%)$; mp 208$212{ }^{\circ} \mathrm{C}$ (dec.); IR (KBr) v / cm ${ }^{-1} 3350,3128,2900,1645$, 1500, 1456, 1300; ${ }^{1} \mathrm{H}$ NMR (250 MHz, DMSO- $\left.d_{6}\right) \delta 8.30$ (s, 1H, C(5)-H, imidazole), 5.40 (s, 2H, $\mathrm{NCH}_{2}$ ), 4.40 (s, $1 \mathrm{H}$, exchangeable with $\mathrm{D}_{2} \mathrm{O}, \mathrm{NH}$, tetrazole), 2.43 (s, 3H, $\left.\mathrm{CH}_{3}\right) ;{ }^{13} \mathrm{C}$ NMR (250 MHz, DMSO- $\left.d_{6}\right) \delta 15.7,48.2,121.1$, 
147.8, 153.0, 160.9; MS (EI): $m / z(\%)=209(8.1)\left[\mathrm{M}^{+}\right]$; anal. calcd. for $\mathrm{C}_{6} \mathrm{H}_{7} \mathrm{~N}_{7} \mathrm{O}_{2}: \mathrm{C}, 34.45 ; \mathrm{H}, 3.37 ; \mathrm{N}, 46.88$; found: C, 34.38; H, 3.42; N, 46.94.

\section{5-((2-Phenyl-1H-imidazol-1-yl)methyl)-1H-tetrazole (2d)}

Recrystallization (EtOAc) afforded a bright brown solid; yield: $1.96 \mathrm{~g}(87 \%)$; $\mathrm{mp} 216-220{ }^{\circ} \mathrm{C}$ (dec.); IR $(\mathrm{KBr}) \vee / \mathrm{cm}^{-1} 3280,3150,2937,2850,1653,1476$; ${ }^{1} \mathrm{H}$ NMR $\left(250 \mathrm{MHz}\right.$, DMSO- $\left.d_{6}\right) \delta$ 7.94-7.91 (m, 2H, aryl), 7.58-7.46 (m, 3H, aryl), 7.20 (s, $1 \mathrm{H}, \mathrm{C}(4)-\mathrm{H}$, imidazole), 6.95 (s, $1 \mathrm{H}, \mathrm{C}(5)-\mathrm{H}$, imidazole), $5.28\left(\mathrm{~s}, 2 \mathrm{H}, \mathrm{NCH}_{2}\right), 2.50$ (s, $1 \mathrm{H}$, exchangeable with $\mathrm{D}_{2} \mathrm{O}, \mathrm{NH}$, tetrazole); ${ }^{13} \mathrm{C}$ NMR $\left(250 \mathrm{MHz}, \mathrm{DMSO}-d_{6}\right) \delta 49.0,121.0,125.5,127.0,127.4$, 129.6, 131.0, 152.1, 160.1; MS (EI): $\mathrm{m} / z(\%)=226(17.3)$ $\left[\mathrm{M}^{+}\right]$; anal. calcd. for $\mathrm{C}_{11} \mathrm{H}_{10} \mathrm{~N}_{6}$ : C, 58.40; $\mathrm{H}, 4.46 ; \mathrm{N}, 37.15$; found: C, 58.31; H, 4.58; N, 37.02.

1-((1H-Tetrazol-5-yl)methyl)pyrimidine-2,4 $(1 H, 3 H)$-dione (2e)

Recrystallization (EtOAc) afforded a creamy solid; yield: $1.61 \mathrm{~g} \mathrm{(83 \% );} \mathrm{mp} \mathrm{285-290}{ }^{\circ} \mathrm{C}$; IR (KBr) v / $\mathrm{cm}^{-1} 3365$, $3129,2876,1723,1706,1650,1458$; ${ }^{1} \mathrm{H}$ NMR $(250 \mathrm{MHz}$, DMSO- $\left.d_{6}\right) \delta 11.37\left(\mathrm{~s}, 1 \mathrm{H}\right.$, exchangeable with $\mathrm{D}_{2} \mathrm{O}, \mathrm{NH}$, uracil), $7.67(\mathrm{~d}, 1 \mathrm{H}, J 7.5 \mathrm{~Hz}, \mathrm{C}(6)-\mathrm{H}$, uracil), $5.70(\mathrm{~d}, 1 \mathrm{H}$, $J 7.5 \mathrm{~Hz}, \mathrm{C}(5)-\mathrm{H}$, uracil), 5.07 (s, 2H, $\mathrm{NCH}_{2}$ ), 4.07 (s, $1 \mathrm{H}$, exchangeable with $\mathrm{D}_{2} \mathrm{O}, \mathrm{NH}$, tetrazole); ${ }^{13} \mathrm{C} \mathrm{NMR}(250 \mathrm{MHz}$, DMSO- $\left.d_{6}\right) \delta 47.3,103.4,142.1,151.5,156.4,161.7$; MS (EI): $m / z(\%)=194(10.8)\left[\mathrm{M}^{+}\right]$; anal. calcd. for $\mathrm{C}_{6} \mathrm{H}_{6} \mathrm{~N}_{6} \mathrm{O}_{2}: \mathrm{C}$, $37.12 ; \mathrm{H}, 3.11 ; \mathrm{N}, 43.29$; found: C, 37.24; H, 3.26; N, 43.24.

\section{9-((1H-Tetrazol-5-yl)methyl)-9H-purin-6-amine (2f)}

Recrystallization (EtOAc) afforded a creamy solid; yield: $1.78 \mathrm{~g}(82 \%) ; \mathrm{mp}>300{ }^{\circ} \mathrm{C}$ (dec.); IR (KBr) $v / \mathrm{cm}^{-1}$ $3328,3100,2853,1676,1520,1471 ;{ }^{1} \mathrm{H}$ NMR $(250 \mathrm{MHz}$, DMSO- $\left.d_{6}\right) \delta 8.12$ (s, $1 \mathrm{H}, \mathrm{C}(8)-\mathrm{H}$, adenine), $8.05(\mathrm{~s}, 1 \mathrm{H}$, $\mathrm{C}(2)-\mathrm{H}$, adenine), 7.17 (s, $2 \mathrm{H}$, exchangeable with $\mathrm{D}_{2} \mathrm{O}$, $\mathrm{NH}_{2}$ ), 5.42 (s, 2H, $\left.\mathrm{NCH}_{2}\right), 4.80$ (s, 1H, exchangeable with $\mathrm{D}_{2} \mathrm{O}, \mathrm{NH}$, tetrazole); ${ }^{13} \mathrm{C}$ NMR $\left(250 \mathrm{MHz}\right.$, DMSO- $d_{6}$ ) $\delta$ 54.3, 118.4, 139.9, 147.7, 151.5, 155.6, 162.8; MS (EI): $m / z(\%)=217(9.5)\left[\mathrm{M}^{+}\right] ;$anal. calcd. for $\mathrm{C}_{7} \mathrm{H}_{7} \mathrm{~N}_{9}: \mathrm{C}, 38.71 ;$ H, 3.25; N, 58.04; found: C, 38.63; H, 3.18; N, 58.12.

\section{2-((1H-Tetrazol-5-yl)methyl)benzo[d]isothiazol-3(2H)-one}

\section{1,1-dioxide (2g)}

Recrystallization (EtOAc) afforded a pale-yellow solid; yield: $2.30 \mathrm{~g}$ (87\%); $\mathrm{mp} 225-229{ }^{\circ} \mathrm{C}$ (dec.); IR $(\mathrm{KBr}) \mathrm{v} / \mathrm{cm}^{-1} 3324,3050,2976,1715,1600,1460,1321$, 761; ${ }^{1} \mathrm{H}$ NMR $\left(250 \mathrm{MHz}\right.$, DMSO- $\left.d_{6}\right) \delta$ 7.84-7.45 (m, 4H, aryl), 4.44 (s, $\left.2 \mathrm{H}, \mathrm{NCH}_{2}\right), 2.51$ (s, 1H, exchangeable with $\mathrm{D}_{2} \mathrm{O}, \mathrm{NH}$, tetrazole); ${ }^{13} \mathrm{C}$ NMR $\left(250 \mathrm{MHz}\right.$, DMSO- $\left.d_{6}\right)$ $\delta 39.5,126.3,126.8,127.3,131.6,132.0,139.3,156.6$,
169.1; MS (EI): $m / z(\%)=265(19.7)\left[\mathrm{M}^{+}\right]$; anal. calcd. for $\mathrm{C}_{10} \mathrm{H}_{8} \mathrm{~N}_{4} \mathrm{O}_{3} \mathrm{~S}: \mathrm{C}, 45.45 ; \mathrm{H}, 3.05 ; \mathrm{N}, 21.20 ; \mathrm{S}, 12.13$; found: C, 45.56; H, 3.11; N, 21.14; S, 12.25 .

\section{2-(2-(1H-Tetrazol-5-yl)ethyl)isoindoline-1,3-dione (2h)}

Recrystallization (EtOAc) afforded a creamy solid; yield: $2.21 \mathrm{~g}(91 \%) ; \mathrm{mp}>300{ }^{\circ} \mathrm{C}$ (dec.); IR (KBr) $\mathrm{V} / \mathrm{cm}^{-1}$ 3374, 3063, 2950, 1772, 1620, 1510, 1458; ${ }^{1} \mathrm{H}$ NMR $\left(250 \mathrm{MHz}\right.$, DMSO- $\left.d_{6}\right) \delta$ 7.28-7.09 (m, 4H, aryl), 4.34 (t, $2 \mathrm{H}, J 7.2 \mathrm{~Hz}, \mathrm{NCH}_{2}$ ), 3.46 (s, $1 \mathrm{H}$, exchangeable with $\mathrm{D}_{2} \mathrm{O}, \mathrm{NH}$, tetrazole), 3.08 (t, $2 \mathrm{H}, J 7.2 \mathrm{~Hz}, \mathrm{NCH}_{2} \mathrm{CH}_{2}$ ); ${ }^{13} \mathrm{C}$ NMR $\left(250 \mathrm{MHz}\right.$, DMSO- $\left.d_{6}\right) \delta 27.6,42.6,126.3,131.6$, 134.2, 159.4, 167.0; MS (EI): $m / z(\%)=243(13.9)\left[\mathrm{M}^{+}\right]$; anal. calcd. for $\mathrm{C}_{11} \mathrm{H}_{9} \mathrm{~N}_{5} \mathrm{O}_{2}$ : C, 54.32; H, 3.73; N, 28.79; found: C, 54.43; H, 3.82; N, 28.86 .

7-(2-(1H-Tetrazol-5-yl)ethyl)-1,3-dimethyl- $1 H$-purine2,6(3H,7H)-dione (2i)

Column chromatography (silica gel, $\mathrm{MeOH}$ ) afforded a brown foam; yield: $2.48 \mathrm{~g}(90 \%)$; IR (KBr) $v / \mathrm{cm}^{-1} 3300$, 2985, 1716, 1702, 1693, 1658, 1379; ${ }^{1} \mathrm{H}$ NMR $(250 \mathrm{MHz}$, DMSO- $\left.d_{6}\right) \delta 7.86$ (s, $1 \mathrm{H}, \mathrm{C}(8)-\mathrm{H}$, theophylline), 4.55 (t, $\left.2 \mathrm{H}, J 5.7 \mathrm{~Hz}, \mathrm{NCH}_{2}\right), 3.41$ (t, $2 \mathrm{H}, J 5.7 \mathrm{~Hz}, \mathrm{NCH}_{2} \mathrm{CH}_{2}$ ), 3.27 (s, 3H, N(1)- $\mathrm{CH}_{3}$ ), 3.09 (s, 3H, N(3)- $\mathrm{CH}_{3}$ ), 2.54 (s, $1 \mathrm{H}$, exchangeable with $\mathrm{D}_{2} \mathrm{O}, \mathrm{NH}$, tetrazole); ${ }^{13} \mathrm{C}$ NMR $\left(250 \mathrm{MHz}, \mathrm{DMSO}-d_{6}\right) \delta 20.1,31.0,32.3,34.5,106.3$, $136.8,145.9,147.7,154.5,159.8 ; \mathrm{MS}(\mathrm{EI}): \mathrm{m} / z(\%)=276$ (20.7) $\left[\mathrm{M}^{+}\right]$; anal. calcd. for $\mathrm{C}_{10} \mathrm{H}_{12} \mathrm{~N}_{8} \mathrm{O}_{2}: \mathrm{C}, 43.48 ; \mathrm{H}, 4.38$; N, 40.56; found: C, 43.59; H, 4.27; N, 40.61 .

\section{5-(2-(2-Phenyl-1H-imidazol-1-yl)ethyl)-1H-tetrazole (2j)}

Recrystallization (EtOAc) afforded a creamy solid; yield: $2.06 \mathrm{~g}(86 \%)$; mp $250-255{ }^{\circ} \mathrm{C}$ (dec.); IR (KBr) $\mathrm{v} / \mathrm{cm}^{-1} 3300,3050,2960,1650,1485 ;{ }^{1} \mathrm{H}$ NMR $(250 \mathrm{MHz}$, DMSO- $\left.d_{6}\right) \delta 7.58-7.44(\mathrm{~m}, 5 \mathrm{H}$, aryl), $7.32(\mathrm{~s}, 1 \mathrm{H}, \mathrm{C}(4)-\mathrm{H})$, 6.95 (s, 1H, C(5)-H), 4.29 (t, 2H, J 7.5 Hz, $\mathrm{NCH}_{2}$ ), 3.07 (t, $\left.2 \mathrm{H}, J 7.5 \mathrm{~Hz}, \mathrm{NCH}_{2} \mathrm{CH}_{2}\right), 1.98$ (s, $1 \mathrm{H}$, exchangeable with $\mathrm{D}_{2} \mathrm{O}, \mathrm{NH}$, tetrazole); ${ }^{13} \mathrm{C}$ NMR $\left(250 \mathrm{MHz}\right.$, DMSO- $\left.d_{6}\right)$ $\delta 30.0,54.5,120.8,125.8,126.3,127.0,127.2,130.2$, 149.7, 155.1; MS (EI): $m / z(\%)=240(15.8)\left[\mathrm{M}^{+}\right]$; anal. calcd. for $\mathrm{C}_{12} \mathrm{H}_{12} \mathrm{~N}_{6}$ : C, 59.99; H, 5.03; N, 34.98; found: C, 60.07; H, 5.16; N, 34.87 .

\section{1-(2-(1H-Tetrazol-5-yl)ethyl)-1H-benzo[d]imidazole (2k)}

Recrystallization (EtOAc) afforded a brown solid; yield: $1.90 \mathrm{~g}(89 \%) ; \mathrm{mp} 300-304{ }^{\circ} \mathrm{C}$ (dec.); IR (KBr) v / cm ${ }^{-1}$ 3326, 3100, 2926, 1653, 1501, 1470; ${ }^{1} \mathrm{H}$ NMR $(250 \mathrm{MHz}$, DMSO- $\left.d_{6}\right) \delta 8.10(\mathrm{~s}, 1 \mathrm{H}, \mathrm{C}(2)-\mathrm{H}$, benzimidazole), 7.62-7.55 (m, 2H, aryl), 7.24-7.14 (m, 2H, aryl), 4.55 (t, 2H, $J 6.5 \mathrm{~Hz}, \mathrm{NCH}_{2}$ ), 3.17 (t, $2 \mathrm{H}, J 6.5 \mathrm{~Hz}, \mathrm{NCH}_{2} \mathrm{CH}_{2}$ ), 2.51 (s, $1 \mathrm{H}$, exchangeable with $\mathrm{D}_{2} \mathrm{O}, \mathrm{NH}$, tetrazole); ${ }^{13} \mathrm{C}$ NMR 
(250 MHz, DMSO- $\left.d_{6}\right) \delta 31.1,60.5,116.1,117.3,124.1$, 125.2, 134.6, 138.7, 149.3, 161.7; MS (EI): $m / z(\%)=214$ (12.7) $\left[\mathrm{M}^{+}\right]$; anal. calcd. for $\mathrm{C}_{10} \mathrm{H}_{10} \mathrm{~N}_{6}$ : $\mathrm{C}, 55.94 ; \mathrm{H}, 4.63$; $\mathrm{N}, 39.14$; found: C, 55.83; H, 4.75; N, 39.28 .

1-(2-(1H-Tetrazol-5-yl)ethyl)-4-phenylpiperazine (2I)

Column chromatography (silica gel, EtOAc- $n$-hexane, 1:1) afforded a bright brown solid; yield: $2.37 \mathrm{~g}$ (92\%); $\mathrm{mp}>300{ }^{\circ} \mathrm{C}$ (dec.); IR (KBr) v / cm ${ }^{-1} 3340,3100,2992$, $1659,1653,1476 ;{ }^{1} \mathrm{H}$ NMR (250 MHz, DMSO- $\left.d_{6}\right)$ $\delta$ 7.26-7.20 (m, 2H, aryl), 6.91-6.81 (m, 3H, aryl), 4.96 (s, $1 \mathrm{H}$, exchangeable with $\mathrm{D}_{2} \mathrm{O}, \mathrm{NH}$, tetrazole), $3.83(\mathrm{t}, 2 \mathrm{H}$, $J 6.5 \mathrm{~Hz}, \mathrm{CH}_{2}$ ), 3.09 (t, $2 \mathrm{H}, J 7.2 \mathrm{~Hz}, \mathrm{CH}_{2}$ ), 2.72-2.65 (m, $\left.8 \mathrm{H}, 4 \mathrm{CH}_{2}\right) ;{ }^{13} \mathrm{C}$ NMR $\left(250 \mathrm{MHz}\right.$, DMSO- $\left.d_{6}\right) \delta 28.2,49.1$, 52.2, 56.1, 114.3, 119.5, 130.5, 150.0, 160.2; MS (EI): $\mathrm{m} / \mathrm{z}$ $(\%)=258(19.7)\left[\mathrm{M}^{+}\right]$; anal. calcd. for $\mathrm{C}_{13} \mathrm{H}_{18} \mathrm{~N}_{6}: \mathrm{C}, 60.44$; $\mathrm{H}, 7.02 ; \mathrm{N}, 32.53$; found: $\mathrm{C}, 60.31 ; \mathrm{H}, 7.08 ; \mathrm{N}, 32.61$.

\section{5-((4-Ethylphenoxy)methyl)-1H-tetrazole (2m)}

Recrystallization (EtOAc) afforded a creamy solid; yield: $1.85 \mathrm{~g}(91 \%)$; $\mathrm{mp} 83-85^{\circ} \mathrm{C}$; IR (KBr) $\mathrm{v} / \mathrm{cm}^{-1} 3300$, 3040, 2957, 1654, 1458; ${ }^{\mathrm{H}} \mathrm{NMR}\left(250 \mathrm{MHz}, \mathrm{DMSO}-d_{6}\right)$ $\delta$ 7.18-7.06 (m, 2H, aryl), 6.97-6.93 (m, 1H, aryl), 6.86-6.77 $(\mathrm{m}, 1 \mathrm{H}$, aryl $), 5.42\left(\mathrm{~s}, 2 \mathrm{H}, \mathrm{OCH}_{2}\right), 4.36(\mathrm{~s}, 1 \mathrm{H}$, exchangeable with $\mathrm{D}_{2} \mathrm{O}, \mathrm{NH}$, tetrazole), 2.57-2.45 (m, $\left.2 \mathrm{H}, \mathrm{CH}_{2} \mathrm{CH}_{3}\right), 1.14$ (t, $\left.3 \mathrm{H}, J 7.5 \mathrm{~Hz}, \mathrm{CH}_{3}\right) ;{ }^{13} \mathrm{C}$ NMR (250 MHz, DMSO- $d_{6}$ ) $\delta$ 14.6, 32.3, 72.1, 115.9, 128.4, 132.4, 155.1, 159.7; MS (EI): $m / z(\%)=204(14.5)\left[\mathrm{M}^{+}\right]$; anal. calcd. for $\mathrm{C}_{10} \mathrm{H}_{12} \mathrm{~N}_{4} \mathrm{O}$ : C, 58.81; H, 5.92; N, 27.43; found: C, 58.89; H, 6.04; N, 27.51 .

5-((3-Chloro-4-methylphenoxy)methyl)-1H-tetrazole (2n)

Recrystallization (EtOAc) afforded a white solid; yield: $1.99 \mathrm{~g}(89 \%)$; $\mathrm{mp} 145-147{ }^{\circ} \mathrm{C}$; IR $(\mathrm{KBr}) \mathrm{v} / \mathrm{cm}^{-1}$ 3250, 3028, 2947, 1657, 1451, 720; ${ }^{1} \mathrm{H}$ NMR $(250 \mathrm{MHz}$, DMSO- $\left.d_{6}\right) \delta 7.04(\mathrm{~d}, 1 \mathrm{H}, J 8.0 \mathrm{~Hz}, \operatorname{aryl}), 6.58(\mathrm{~d}, 1 \mathrm{H}$, $J 8.0 \mathrm{~Hz}$, aryl), 6.49 (s, $1 \mathrm{H}$, aryl), $5.61\left(\mathrm{~s}, 2 \mathrm{H}, \mathrm{OCH}_{2}\right), 4.62$ (s, $1 \mathrm{H}$, exchangeable with $\mathrm{D}_{2} \mathrm{O}, \mathrm{NH}$, tetrazole), 2.47 (s, $\left.3 \mathrm{H}, \mathrm{CH}_{3}\right) ;{ }^{13} \mathrm{C}$ NMR $\left(250 \mathrm{MHz}\right.$, DMSO- $\left.d_{6}\right) \delta 20.1,70.8$, 114.7, 116.4, 125.5, 129.0, 138.8, 155.9, 158.4; MS (EI): $\mathrm{m} / z(\%)=224(19.1)\left[\mathrm{M}^{+}\right]$; anal. calcd. for $\mathrm{C}_{9} \mathrm{H}_{9} \mathrm{ClN}_{4} \mathrm{O}: \mathrm{C}$, 48.12; H, 4.04; Cl, 15.78; N, 24.94; found: C, 48.05; H, 4.07; Cl, 15.71; N, 25.03.

\section{5-((4-Chlorophenoxy)methyl)- $1 \mathrm{H}$-tetrazole (20)}

Recrystallization (EtOAc) afforded a bright brown solid; yield: $1.89 \mathrm{~g}(90 \%)$; mp 241-245 ${ }^{\circ} \mathrm{C}$; IR (KBr) $\mathrm{V} / \mathrm{cm}^{-1}$ 3270, 3062, 2981, 1654, 1469, 715; ${ }^{1} \mathrm{H}$ NMR $\left(250 \mathrm{MHz}, \mathrm{DMSO}-d_{6}\right) \delta 7.13(\mathrm{~d}, 2 \mathrm{H}, J 8.8 \mathrm{~Hz}$, aryl), 6.91 (d, $2 \mathrm{H}, J 8.8 \mathrm{~Hz}$, aryl), 5.05 (s, 2H, $\mathrm{OCH}_{2}$ ), 4.39 (s, $1 \mathrm{H}$, exchangeable with $\mathrm{D}_{2} \mathrm{O}, \mathrm{NH}$, tetrazole); ${ }^{13} \mathrm{C}$ NMR
(250 MHz, DMSO- $\left.d_{6}\right) \delta 71.2,116.3,127.4,129.7,154.7$, 159.0; $\mathrm{MS}(\mathrm{EI}): m / z(\%)=210(18.1)\left[\mathrm{M}^{+}\right]$; anal. calcd. for $\mathrm{C}_{8} \mathrm{H}_{7} \mathrm{ClN}_{4} \mathrm{O}: \mathrm{C}, 45.62 ; \mathrm{H}, 3.35 ; \mathrm{Cl}, 16.83 ; \mathrm{N}, 26.60$; found: C, $45.69 ; \mathrm{H}, 3.43 ; \mathrm{Cl}, 16.80 ; \mathrm{N}, 26.67$.

\section{Supplementary Information}

${ }^{1} \mathrm{H}$ and ${ }^{13} \mathrm{C}$ NMR spectra of synthesized tetrazoles are available free of charge at http://jbcs.sbq.org.br as PDF file.

\section{Acknowledgments}

The author is grateful to Shiraz University of Technology Research Councils for partial support of this work.

\section{References}

1. Butler, R. N. In Comprehensive Heterocyclic Chemistry II, vol. 4; Katritzky, A. R.; Rees, C. W.; Scriven, E. F. V., eds.; Pergamon: Oxford, 1996, p. 897.

2. Ostrovskii, V. A.; Koldobskii, G. I.; Trifonov, R. E. In Comprehensive Heterocyclic Chemistry III, vol. 6; Katritzky, A. R.; Ramsden, C. A.; Scriven, E. F. V.; Taylor, R. J. K., eds.; Elsevier: Oxford, 2008, p. 257.

3. Jursic, B. S.; Leblanc, B. W.; J. Heterocycl. Chem. 1998, 35, 405 and references cited therein.

4. Koldobskii, G. I.; Ostrovskii, V. A.; Popavskii, V. S.; Khim. Geterotsikl. Soedin. 1981, 10, 1299.

5. Zhao-Xu, C.; Heming, X.; Int. J. Quantum Chem. 2000, 79, 350.

6. Kharaghiosoff, K.; Klapotke, T. M.; Mayer, P.; Piotrowski, H.; Polborn, K.; Willer, R. L.; Weigand, J. J.; J. Org. Chem. 2006, $71,1295$.

7. Hammerl, A.; Hiskey, M. A.; Holl, G.; Klapoetke, T. M.; Polborn, K.; Stierstorfer, J.; Weigand, J. J.; Chem. Mater. 2005, 17, 3784 .

8. Downard, A. J.; Steel, P. J.; Steenwijk, J.; Aust. J. Chem. 1995, 48, 1625.

9. Mukhopadhyay, S.; Lasri, J.; Guedes da Silva, M. F. C.; Januário Charmier, M. A.; Pombeiro, A. J. L.; Polyhedron 2008, 27, 2883.

10. McManus, J. M.; Herbst, R. M.; J. Org. Chem. 1959, 24, 1464.

11. Li, J.; Ren, T.; Liu, H.; Wang, D.; Liu, W.; Wear 2000, 246, 130.

12. Herr, R. J.; Bioorg. Med. Chem. 2002, 10, 3379.

13. Meanwell, N. A.; J. Med. Chem. 2011, 54, 2529.

14. Pegklidou, K.; Koukoulitsa, C.; Nicolaou, I.; Demopoulos, V. J.; Bioorg. Med. Chem. 2010, 18, 2107.

15. Holland, G. F.; Pereira, J. N.; J. Med. Chem. 1967, 10, 149.

16. Marvi, O.; Alizadeh, A.; Zarrabi, S.; Bull. Korean Chem. Soc. 2011, 32, 4001.

17. Aureggi, V.; Sedelmeier, G.; Angew. Chem., Int. Ed. 2007, 46, 8440 . 
18. Alonen, A.; Finel, M.; Kostiainen, R.; Biochem. Pharmacol. 2008, 76, 763.

19. Alonen, A.; Jansson, J.; Kallonen, S.; Kiriazis, A.; Aitio, O.; Finel, M.; Kostiainen, R.; Bioorg. Chem. 2008, 36, 148.

20. Bräuner-Osborne, H.; Egebjerg, J.; Nielsen, E. O.; Madsen, U.; Krogsgaard-Larsen, P.; J. Med. Chem. 2000, 43, 2609.

21. Lusina, M.; Cindrić, T.; Tamaić, J.; Peko, M.; Pozaić, L.; Musulin, N.; Int. J. Pharm. 2005, 291, 127.

22. Narasaiaha, T.; Subba Raoa, D.; Rasheeda, S.; Madhavaa, G.; Srinivasulua, D.; Brahma Naidub, P.; Naga Rajua, C.; Der Pharm. Lett. 2012, 4, 854.

23. Andrus, A.; Partridge, B.; Heck, J. V.; Christensen, B. G.; Tetrahedron Lett. 1984, 25, 911.

24. Dhayanithhi, V.; Syed, S. S.; Kumaran, K.; Sankar, K. R. J.; Ragavan, R. V.; Goud, P. S. K.; Kumari, N. S.; Pati, H. N.; J. Serb. Chem. Soc. 2011, 76, 165.

25. Rajasekaran, A.; Sankaranarayanan, M.; Rajagopal, K. A.; Arch. Pharm. Res. 2006, 29, 535.

26. Upadhayaya, R. S.; Jain, S.; Sinha, N.; Kishore, N.; Chandra, R.; Arora, S. K.; Eur. J. Med. Chem. 2004, 39, 579.

27. Mohite, P. B.; Pandhare, R. B.; Khanage, S. G.; Bhaskar,V. H.; J. Pharm. Res. 2010, 3, 43.

28. Maxwell, J. R.; Wasdahl, D. A.; Wolfson, A. C.; Stenberg, V. I.; J. Med. Chem. 1984, 27, 1565.

29. Adamec, J.; Waisser, K.; Kunes, J.; Kaustova, J.; Arch. Pharm. $\mathbf{2 0 0 5}, 338,385$.

30. De Souza, A. O.; Pedrosa, M. T.; Alderete, J. B.; Cruz, A. F.; Prado, M. A.; Alves, R. B.; Silva, C. L.; Pharmazie 2005, 60, 396.

31. Akimoto, H.; Ootsu, K.; Itoh, F.; Eur. Patent EP 530,537 1993 (CA 119:226417).

32. Peet, N. P.; Baugh, L. E.; Sunder, S.; Lewis, J. E.; Matthews, E. H.; Olberding, E. L.; Shah, D. N.; J. Med. Chem. 1986, 29 , 2403.

33. Ellis, G. P.; Shaw, D.; J. Med. Chem. 1972, 15, 865.

34. Nohara, A.; Kuriki, H.; Saijo, T.; Sugihara, H.; Kanno, M.; Sanno, Y.; J. Med. Chem. 1977, 20, 141.

35. Vieira, E.; Huwyler, S.; Jolidon, S.; Knoflach, F.; Mutel, V.; Wichmann, J.; Bioorg. Med. Chem. Lett. 2005, 15, 4628.

36. Gagnon, A.; Landry, S.; Coulombe, R.; Jakalian, A.; Guse, I.; Thavonekham, B.; Bonneau, P. R.; Yoakim, C.; Simoneau, B.; Bioorg. Med. Chem. Lett. 2009, 19, 1199.

37. Katritzky, A. R.; Cai, C.; Meher, N. K.; Synthesis 2007, 1204 and all references cited therein.

38. Patil, U. B.; Kumthekar, K. R.; Nagarkar, J. M.; Tetrahedron Lett. 2012, 53, 3706.
39. Demko, Z. P.; Sharpless, K. B;. J. Org. Chem. 2001, 66, 7945.

40. Himo, F.; Demko, Z. P.; Noodleman, L.; Sharpless, K. B.; J. Am. Chem. Soc. 2003, 125, 9983.

41. Roh, J.; Vávrová, K.; Hrabálek, A.; Eur. J. Org. Chem. 2012, 6101.

42. Voitekhovich, S. V.; Ivashkevich, O. A.; Gaponik, P. N.; Russ. J. Org. Chem. 2013, 49, 635.

43. Sreedhar, B.; Kumar, A. S.; Yada, D.; Tetrahedron Lett. 2011, 52,3565 .

44. Nasrollahzadeh, M.; Bayat, Y.; Habibi, D.; Moshaee, S.; Tetrahedron Lett. 2009, 50, 4435.

45. Du, Z.; Si, C.; Li, Y.; Wang, Y.; Lu, J.; Int. J. Mol. Sci. 2012, 13, 4696.

46. Esmaeilpour, M.; Javidi, J.; Nowroozi Dodeji, F.; Mokhtari Abarghoui, M.; J. Mol. Catal. A: Chem. 2014, 393, 18.

47. Najafi Chermahini, A.; Teimouri, A.; Momenbeik, F.; Zarei, A.; Dalirnasab, Z.; Ghaedi, A.; Roosta, M.; J. Heterocycl. Chem. 2010, 47, 913.

48. Teimouri, A.; Najafi Chermahini, A.; Polyhedron 2011, 30, 2606.

49. Nasrollahzadeh, M.; Habibi, D.; Shahkarami, Z.; Bayat, Y.; Tetrahedron 2009, 65, 10715.

50. Sharghi, H.; Ebrahimpourmoghaddam, S.; Doroodmand, M. M.; J. Organomet. Chem. 2013, 738, 41.

51. Dehghani, F.; Sardarian, A. R.; Esmaeilpour, M.; J. Organomet. Chem. 2013, 743, 87.

52. Kantam, M. L.; Shiva Kumar, K. B.; Phani Raja, K. J.; J. Mol. Catal. A: Chem. 2006, 247, 186.

53. Lakshmi Kantam, M.; Balasubrahmanyam, V.; Shiva Kumar, K. B.; Synth. Commun. 2006, 36, 1809.

54. He, J.; Li, B.; Chen, F.; Xu, Z.; Yin, G.; J. Mol. Catal. A: Chem. 2009, 304, 135.

55. Lang, L.; Zhou, H.; Xue, M.; Wang, X.; Xu, Z.; Mater. Lett. 2013, 106, 443.

56. Soltani Rad, M. N.; Behrouz, S.; Doroodmand, M. M.; Movahediyan, A.; Tetrahedron 2012, 68, 7812.

57. Soltani Rad, M. N.; Behrouz, S.; Faghihi, M. A.; J. Iran Chem. Soc. 2014, 11, 361.

58. Soltani Rad, M. N.; Behrouz, S.; Doroodmand, M. M.; Moghtaderi, N.; Synthesis 2011, 3915.

59. Reichardt, C.; Solvents and Solvent Effects in Organic Chemistry; VCH Verlagsgesellschaft mbH: Weinheim, 1988.

Submitted: March 2, 2016

Published online: May 5, 2016 